\title{
THE USE OF ELECTRONIC-BASED EDUCATIONAL GAME TOOL "SMART HAFIZ" IN STIMULATING EARLY CHILDHOOD DEVELOPMENTIN THE PANDEMIC ERA
}

\author{
Sofia Rizki Julianti ${ }^{1}$, Erni Munastiwi² \\ ${ }^{1,2}$ UIN Sunan Kalijaga, Yogyakarta
}

\begin{abstract}
Problems that occur during pandemics, especially in early childhood education, begin when the learning system is implemented at home. Early childhood needs special attention in its development, requires assistance and fulfillment of its needs during the pandemic, including the procurement of facilities that support children's learning. This study aims to examine the electronic-based educational game tool "Smart Hafidz" which is expected to present as a solution to learning problems that occurred during the pandemic. This type of research uses a qualitative approach through review literature, with study and look at existing literature related to this research. Based on the results of this study, the presence of several educational game tools, one of which is Smart Hafidz can be used as one of the problems in stimulation early childhood development during the pandemic. Stimulation through Smart Hafidz contained in the development of art, language, and most importantly the development of moral and religious values.
\end{abstract}

Keywords: Educational Game Tools, Smart Hafidz, Early Childhood, Pandemic

\begin{abstract}
Abstrak: Permasalahan yang terjadi saat pandemi khususnya dalam pendidikan untuk anak usia dini, dimulai saat diterapkan sistem pembelajaran di rumah. Anak usia dini memerlukan perhatian yang khusus di masa perkembangannya, membutuhkan pendampingan dan pemenuhan kebutuhannya selama masa pandemi berlangsung, termasuk pengadaan fasilitas yang menunjang pembelajaran anak. Penelitian ini betujuan mengkaji alat permainan edukatif berbasis elektronik yaitu "Smart Hafidz" yang diharapkan hadir sebagai penyelesaian dari permasalahan pembelajaran yang terjadi di masa pandemi. Jenis penelitian ini menggunakan pendekatan kualitatif melalui literatur review, dengan kajian dan melihat literatur yang ada yang berkaitan dengan penelitian ini. Berdasarkan hasil dari penelitian ini hadirnya beberapa alat permainan edukatif salah satunya Smart Hafidz bisa dijakan sebagai salah satu pemecahan permasalahan terhadap pemberian stimulasi pekembangan anak usia dini selama masa pandemi. Pemberian stimulasi melaui Smart Hafidz yang terdapat pada perkembangan seni, bahasa dan yang terpenting perkembangan nilai-nilai moral dan agama.
\end{abstract}

Kata Kunci: Alat Permainan Edukatif, Smart Hafidz, Anak Usia Dini, Pandemi

\footnotetext{
' UIN Sunan Kalijaga, Yogyakarta, Email: 20204031022@student.uin-suka.ac.id

${ }^{2}$ UIN Sunan Kalijaga, Yogyakarta, Email: erni.munastiwi国uin-suka.ac.id
} 


\section{INTRODUCTION}

All face-to-face implementation processes in learning during the covid pandemic are required to stop, without exception the implementation of learning from kindergarten to lectures is required to follow online learning. In the implementation of learning online many things that must be considered are certainly not easy in its implementation, apart from that also because this is a new thing that began to be applied nationally in Indonesia. The government, teachers, parents, and students are required to be actively involved in succeeding in the learning process online so that it is expected to be by educational goals. Online learning policies that have been established by the government and applied nationally, such as in early childhood learning that requires special attention. As it is known that early childhood is a child who is in the age of needing special treatment, such as the provision of activities that are stimulations of various developments.

The habits that occur before the pandemic in the task of providing parental stimulation are burdensome to schools, but in the current pandemic, the role of both is needed. Schoolwork in online learning in this kindergarten by providing daily tasks, and parents accompany children in doing them. The lack of maximum learning done online affects most early childhood development for its achievement during this pandemic is decreasing (Wulandari $\&$ Purwanta, 2020). Because of the many things that are now limited, which affects the provision of stimulation to children such as the learning process in school that directly affects the time and place where children play.

Accompanying, paying attention to everything needed by children in the pandemic period, is an important role that must be given and carried out by parents. This is related to the feelings of children during pandemics, so keep children from feeling alone and excited. Parents can facilitate the needs of children to create an environment conducive to learn and can conduct discussion activities that can help children in recognizing, seeing, and developing something that is in the child related to the child's interests and talents (Iftitah \& Anawaty, 2020). The role of parents can also be a bridge in the learning process for children, such as in the development of creativity when parents do not have conformity to the purpose of providing education (Sartika $\&$ Munastiwi, 2019). This study provided insights for parents able to take a very careful attitude in the determination and procurement of adequate facilities for children by paying attention to several aspects. Various demands of parental activities are different, so most parents look for ways related to the provision of stimulations and the provision of facilities in meeting the needs of children when online learning takes place.

Parents are looking for educational and effective game tools which are also easy to use by children. Most parents give electronic-based games such as giving mobile phones, watching tv, and so on. Smart video media hafiz comes as an electronic-based educational game tool. The presence of the latest product innovations from $\mathrm{Al}$ Qolam as a medium is Smart Hafiz. Electronic-based children's educational products with Islamic content that has a lot of educational value and fun for children. Based on these problems, the interest of researchers is in reviewing how to use electronic-based educational game tools "smart hafiz" to early childhood in the pandemic.

\section{Early Childhood Education in Pandemic Era}

The order of human life has changed in all areas of life, the spread of pandemic outbreaks by the Covid-19 virus that spread to all corners of the world, as well as policies made such as 
maintaining physical distance and maintaining social distance. One of the orders of life that are greatly influenced by the outbreak of this virus is in the world of education. Government policies implemented during the pandemic, namely learning are carried out independently at home online, it is an option that cannot be avoided and cannot be avoided also in its implementation as a trigger for the emergence of new problems in the field of education for early childhood learning (Pramana, 2020).

Early childhood is an individual who is between the ages of 0 to 6 years. Psychologists express various opinions that early childhood is categorized as children with groupage, age of exploration, age of questioning, age of imitation. (Mashar, 2011). Both educational institutions, teachers, children, and parents feel a lot of problems. The achievement of appropriate child development in his time will lead the child to succeed in the future. (Yus, 2011) The comparisons made related to the implementation of learning in school and at home feel very different. The differences that are felt begin in terms of the learning process related to methods when learning, the involvement of children in response to the subject matter, so that the impact can affect health on mental and social aspects of children (Pramana, 2020).

The main key today can be relied upon, namely both mothers and fathers who have a crucial role in determining the running of children's learning activities during this online system is applied at home. An effective way that can be done now is to first by entering both children, (Susanto, 2011) understand different approaches in learning that differ into a child's learning style or preparation related to a conducive and comfortable learning environment (Ahsani, 2020). Motivation in parents and teachers should remain high, to align themselves with teaching in times of pandemic. Parents who faithfully accompany their children to learn at home, while maintaining the child's spirit to learn other than that, maintaining in terms of children's health is a form of the purpose of learning implementation from as positive policy support from the government (Pramana, 2020).

The effectiveness of online learning in educational institutions for early childhood held in pandemic times can be said to be in conditions that cannot run effectively. Made clear by the findings made in a study states that some educators are declared not to be learning in pandemic times, for some underlying reasons. Given that online learning is carried out without observing as in the daily learning implementation plan that has been made, the parameters of learning that is implemented are not appropriate and evaluated. In addition, the problem of the number of technical complaints felt by educators will be their differences of opinion regarding online learning. The effectiveness of learning from what is felt less and other problems are not all parents who have tools that support the learning such as laptops or gadgets (Nurdin \& Anhusadar, 2020).

\section{Electronic-Based Educational Gaming Tools}

Educational game tools are a medium that has been arranged and adapted as a support in the implementation of the child's education process through learning. The continuity of the learning process of early childhood education cannot be separated from a tool called media, the characteristics displayed from a learning medium that is tailored to the needs of children, namely playing while learning(Zaini \& Dewi, 2017). Play for early childhood requires media that is used as a provision of stimulation activities all things related to the development of children(Hendayani, 
2012). So that playing activity using learning media can help with the provision of stimulation for all aspects of development.

A lot of educational media are used as a tool to support the success of children's learning such as game tools that are created by themselves from simple materials or produced by factories. Looking at current circumstances and developments has its challenges that are felt in raising children in the information age (Gomes, 2019). Parents who cannot take advantage of the situation creatively and anticipate, impact instead of utilizing information technology appropriately but become victims of the technology. Playing using electronic-based media does not always bring bad effects in the morning of its users. When use is done correctly and does not contradict the age of the child. The simplest thing is often found in daily activities that chatter directly with the use of gadgets, TV and electronic-based educational game tools can be a benefit for its users.

Electronic-based game tools for children if studied and used wisely, when compared to conventional forms of gaming in general electronic-based games have more advantages, in addition to being able to accommodate various data through large storage space and provide convenience for users. Gadgets and the like can be categorized as electronic gaming tools that are environmentally friendly such as without excessive paper use. (Saputra \& Ekawati, 2018) Electronic-based game tools are used as interactive media, a means of developing creativity and providing fulfillment of facilities to children whose age has different learning needs. (Alia \& Irwansyah, 2018)

\section{Smart Hafiz}

Technological advances provide all the convenience for humans in carrying out their daily activities. Ease and speed obtained such as in accessing information requires a wise attitude and also appropriate so that the development and advancement of technology can provide benefits for humans, as well as in the family environment, especially in how to educate children. Given the technological advances felt in the sophisticated era that rapidly presents technology in the form of the latest electronic-based products such as smartphones, computers, and various entertainment applications and learning applications that are connected using the Internet that can be accessed by various ages. The use of electronic media must be done wisely, of course, because the media used is not responsible for what makes cause and effect in its use. (Alia \& Irwansyah, 2018)

Smart Hafiz game is one of the latest introductions from $\mathrm{Al}$ Qolam, an educational product that contains a lot of fun educational content, for Islamic children. The best quality given from a game tool is in the form of an excellent sound, with karaoke features as a medium for children to perform preaching and singing activities (Nurwita, 2020). Many of the features offered by Smart Hafiz and electronicbased games can be introduced in early childhood because this nursery tool is designed and adapted to the characteristics of children. Smart Hafiz features that contain about 300 Islamic content such as (Salamah et al., 2020).

First, audio-video content such as singing songs that contain body-themed content consisting of 44 songs, 37 Muslim children's songs, juz 30, etc.

Second, learn which contains the Al-Qolam method which contains knowing hijaiyah letters to know readings, murotal 30 juz with the use of USB, audiovisual asmaulhusna, and small da'i.

Third, stories containing Islamic content such as Muslim holiday stories, Islamic history traces of 15 cities around 
the world, Hafiz and Hafizah Umrah by telling the rituals of Hajj and Umrah, the story of 25 prophets, etc.

Fourth, the film contains preschool animation such as color recognition, letter recognition, number recognition, learning to read, counting, etc. Fifth, noble morals contain nine moral stories in a child's daily life.

\section{METHODOLOGY}

This study is a study that uses qualitative data. (Anggito \& Setiawan, 2018,) This research collects data related to research, using the approach of literature study methods. The object of this research discussion is about the use of educational game tools in pandemic times and educational games "Smart Hafiz".

Data collection techniques related to research conducted are in the form of secondary data collection related to this research. The source of information obtained by analyzing data to find results thoroughly, to provide a theoretical and conceptual picture of a problem related to the use of electronic-based educational game tools "smart hafiz" too early childhood in the pandemic period. Literature reviews were conducted in this study using literature studies obtained from books and related literature searches on electronic databases such as google scholar data searches.

This research data analysis technique, by reviewing and analyzing the existing literature, concerning values such as accuracy, clarity, empirical, relevance related to the source of the library to be reviewed. Data analysis techniques used in this study namely, data collection, data reduction, presentation of data to conclusion withdrawal, and verification.

\section{RESULT}

\section{Parents In Determining Educational Gaming Tools}

Early childhood during pandemics has a major impact, including on early childhood development. Important events that change from a family life order, through learning activities from home can be the recreation of a family role. The main family plays an important role in the development of parents, many interactions are done with children so that parents can maximize their role in educating children. Various game tools for children after early, with various functions of the game tool. Such as game tools that hone the creativity and development of children (Mutiah, 2015). The provision of supporting game tools during this pandemic period is needed. In addition to the demands of online learning, parents also want game tools that they feel can be used easily and effectively.

As the child's main educator during home learning, parents, can start by providing time, preparing the learning environment to be a diverse and fun learning resource so that children can still develop and achieve various aspects of their development. Accompanying children at home can build close relationships between parents and children with the provision of internal strength related to the emotional approach given by parents to children. (Munastiwi, 2020) Communication built by parents is very influential in the child's openness and freedom in expressing feelings, so for the pandemic of mental health children must be considered. (Djayadin \& Munastiwi, 2020) From the background of the problems about what is happening at this time many things are shown by parents from the upper-middle class in the tendency to provide digital media such as gadgets, computers, and television that are used as playing media and media that help the child's learning process.

Some of the factors that some parents facilitate by giving gadgets to children with goals as a medium of play and learning. Following the current 
globalization and the criteria of children at this timeless interest in children to learn with the media generally such as books (Mintorogo et al., 2014). The role of parents in utilizing media that are now very accessible such as online media must look in terms of learning and terms of increasing creativity in children. Especially during the current pandemic with social distancing systems. (Ardiyanti \& Munastiwi, 2020) Educational games if not used wisely and provide educational delivery by parents, will not educate children (Askar, 2015).

\section{Use of "Smart Hafiz" in Pandemic Times}

Smart Hafiz media offers features that are packaged very modern and easy to use by children, the content contained in Smart Hafiz media also varies, thus Smart Hafiz media can make children feel relaxed and relaxed while still learning (Nurwita, 2020). Seeing also the condition of early childhood in the pandemic period that requires more attention to its development and especially on mental health.

The update on Smart Hafidz version 3 to version 4, and now version 5 which the difference is visible in the latest material and appearance and more practically looks the difference as in the screen, button model, and others. While the features are still the same as the previous version. All the features that have been designed and the shape or packaging of this Smart Hafidz have been adapted to the characteristics of the child. Indicators of all aspects of development in early childhood have been designed in Permendikbud no. 137 of 2014, as a benchmark form in child development. Media such as Smart Hafiz are adapted and based on early childhood learning as a means for children in creating, playing and having fun. When the child experiences a pleasant feeling towards his game, and the child enjoys the moment the child plays to create a feeling of pleasure for the child. The pleasure felt by the child, will facilitate the process of the child is receiving an understanding that can be in play activities (Nurwita, 2020).

\section{Smart Hafidz and Early Childhood Development}

The accuracy of the use of educational games given to children at an early age is very important to note(Hasanah, 2019). The fulfillment of children's needs can be done by covering all child development (Suryana,2016). The use of Smart Hafidz media by making adjustments related to characteristics and development in children. Some indicators of achievement in the use of Smart Hafiz media in the stimulation of early childhood development will be described in the following paragraph.

First, the development of children's art skill using smart hafiz media is developed very well. The media used is very modern and interesting so this becomes something new for the child and can stimulate the child's curiosity. The media user has a lot of content that supports the development of children's art, which can help children in developing all abilities of children (Huliyah, 2017). As for the advice that can be given specifically for early childhood education teachers that to improve children's art not only use media such as picture books, the use of media that can support the development of children's art must be further improved so that children become more fun, excited and creative (Nurwita, 2020).

Second, Children's toys Smart Hafiz Series Worship on the development of moral values. There is a difference when children are given video and audio media that are packaged in a contemporary manner in the application of moral values, without being given media. (Lestariningrum, 2014), The results in the study stated that the moral value contained in Smart Hafiz children's toys describes simply the many 
deviations of attitudes found in real life, and the aim for early childhood is not to follow negative attitudes because those attitudes are not followed well by children in real life (Salamah et al., 2020).

Third, the use of educational game tool applications in early childhood makes it easier for children to develop their literacy. (Widayati dkk., 2021), The importance of the influence exerted from the video-based educational game tool Smart Hafiz Good categories in activities indicated by children include criteria to develop according to expectations as an implication of the application of smart video learning media hafiz. (Anggraeni \& Gustiana, 2019)

\section{DISCUSSION}

During this pandemic, problems were due to the enactment of online systems with all its problems in the realm of early childhood education, which demanded the tools of the nursery as educational facilities at home. A wise parent is not only seen in terms of the child's interest in the media but seen the value contained in the game tool.

Research conducted by researchers related to the use of electronic-based educational game tools "Smart Hafiz" too early childhood in the transition period, namely the COVID-19 pandemic is a type of research that has not been done before. Research has existed before in the pandemic period, which discusses many programs that switch systems with online-based such as in the implementation of the Qur'anic Tahfidzul, with the provision of tasks consisting of addition and repetition of memorization of the Qur'an (Mubarakah $\&$ Munastiwi, 2020). But in the realm of early childhood, the provision of Smart Hafidz games as a solution can be given as a solution, judging from the characteristics of early childhood.

Smart Hafidz is a game tool that contains Islamic content, as a medium that has an educational nature for the introduction of children to be true Muslims. Parents can choose APE Smart Hafiz as a medium of learning as knowledge of religion and make memorization of the Qur'an, which in the pandemic period children do not get because of the state of online learning. Although in times of pandemic, children cannot do face-to-face learning, the completion of early childhood development tasks can remain by expectations and developmental stimulation can continue to be given to children.

As a parent for early childhood, in this pandemic period is required to be wise in the interests of children's education. In the transition period of habits concerning everything, which is felt less in the provision of stimulation for children. Wise parents are highly expected by early childhood. The development and mental health of children, making the main focus in this pandemic period. So that parent who should be able to be the closest to the child who helps children in completing developmental tasks in their time.

The implications of this study, as an impact of the results of this study for parents who accompany their children in going through these critical times. And the game tools provided by parents influence children's health, which makes it one of the concerns for parents (Eliyanti, 2020).

The results of research state that Smart Hafidz game tools can be used as a medium that has an educational element and is used as a medium that accompanies children in the pandemic period. Because in a game tool for early childhood, Smart Hafidz has the advantages presented in Islamic content contained in the game tool. Early childhood development such as the development of art, language, and religious and moral values of children 
can be stimulated with the help of Smart Hafidz game tools.

Now the priority of children is more important in addition to the health of children, children's education in this pandemic period is also a concern for parents. The presence of the Smart Hafidz game tool comes as an educational game tool that is utilized in this pandemic period and seen in terms of its users that is by early childhood.

In its implementation, the use of Smart Hafidz educational game tools for early childhood in this pandemic period can provide benefits despite some obstacles. The obstacles that arise are caused by the busyness of different working parents so that the child's assistance in playing Smart Hafidz becomes hampered. But in the overall the of Smart Hafidz to stimulate children's development in the pandemic period can be resolvedby the participation of children when playing Smart Hafidz.

\section{CONCLUSION}

From the results of research conducted by researchers can be concluded that the variety of educational game tools offered in meeting the needs of children in their development. Early childhood is one of the children who are at a precarious age and is considered important with the provision of stimulation to all aspects of development is much needed at the age of 0-6 years. As is known at the time of the emigrant, it is a time of transition to a new habit. As with the application of online-based learning, this learning process requires the role of parents. The role of parents can be done through meeting the needs of children by providing educational game tools, namely "Smart Hafidz".

The advantage of the results of this study is to explain about the utilization provided by Smart Hafidz is a medium that can provide stimulation of development that during the pandemic is needed by children, one of which is the development of art, language, and most importantly moral values.

The disadvantage of this study is, researchers only look at the review literature by only looking at existing literature. Researchers do not see and observe children's activities directly, in utilizing educational game tools in this pandemic period.

\section{REFERENCES}

Ahsani, E. L. F. (2020). Strategi Orang Tua dalam Mengajar dan Mendidik Anak dalam Pembelajaran At The Home Masa Pandemi Covid-19. Al Athfal: Jurnal Kajian Perkembangan Anak Dan Manajemen Pendidikan Usia Dini, 3(1), 37-46.

Alia, T., \& Irwansyah, I. (2018). Pendampingan Orang Tua pada Anak Usia Dini dalam Penggunaan Teknologi Digital [Parent Mentoring of Young Children in the Use of Digital Technology]. Polyglot: Jurnal Ilmiah, 14(1), 65-78. https://doi.org/10.19166/pji.v14i1.63 9

Anggito, A., \& Setiawan, J. (2018). Metodologi penelitian Kualitatif. Jejak.

Anggraeni, D., \& Gustiana, E. (2019). Pengaruh Media Pembelajaran Video Smart Hafiz Terhadap Keterampian Bicara Anak. Jurnal Pelita PAUD, 4(1), 139-149. https://doi.org/10.33222/pelitapaud.v $4 \mathrm{i} 1.676$

Ardiyanti, S., \& Munastiwi, E. (2020). Artikel: PERAN ORANG TUA DALAM MEMANFAATKAN MEDIA SOSIAL BAGI ANAK MASA SOCIAL DISTANCING. EARLY CHILDHOOD: JURNAL PENDIDIKAN, 4(2), 31-42. https://doi.org/10.35568/earlychildho od.v4i2.860

Askar, A. W. M. (2015). Al-quran dan Pemanfaatan Permainan Edukatif pada Anak Usia Dini. Al-Afkar: Jurnal Keislaman \& Peradaban, $3(1)$.

Djayadin, C., \& Munastiwi, E. (2020). Pola Komunikasi Keluarga Terhadap Kesehatan Mental Anak Di Tengah 
Pandemi Covid-19. Raudhatul Athfal: Jurnal Pendidikan Islam Anak Usia Dini, 4(2), 160-180.

Eliyanti, Y. (2020). PENGARUH PENDIDIKAN KESEHATAN TENTANG ALAT PERMAINAN EDUKATIF (APE) DENGAN PERKEMBANGAN ANAK USIA TODDLER (1-3 TAHUN) DI PAUD AULADUNA KOTA BENGKULU. Mitra Raflesia (Journal of Health Science), 10(1), Article 1. https://doi.org/10.37638/mitraraflesia .v10i1.2

Gomes, F. D. (2019). PELATIHAN PEMBUATAN APE: SOLUSI ATAS KESULITAN MENSTIMULASI

PERKEMBANGAN AUD BAGI GURU DI PKG CA NAI, CIBAL. Randang Tana - Jurnal Pengabdian Masyarakat, 2(2), 105-112.

Hasanah, U. (2019). PENGGUNAAN ALAT PERMAINAN EDUKATIF (APE) PADA TAMAN KANAK-KANAK SE-KOTA METRO. AWLADY: Jurnal Pendidikan Anak, 5(1), 2040.

https://doi.org/10.24235/awlady.v5i1 .3831

Hendayani, E. S. (2012). PEMANFAATAN ALAT PERMAINAN EDUKATIF (APE) DALAM PEMBELAJARAN PAUD SEATAP MARGALUYU KECAMATAN CIPATAT KABUPATEN BANDUNG BARAT. EMPOWERMENT: Jurnal Ilmiah Program Studi Pendidikan Luar Sekolah, 1(2), 92-104. https://doi.org/10.22460/empowerme nt.v1i2p92-104.620

Huliyah, M. (2017). PENGEMBANGAN DAYA SENI PADA ANAK USIA DINI. As-Sibyan: Jurnal Pendidikan Anak Usia Dini, 1(02), 149-164.

Iftitah, S. L., \& Anawaty, M. F. (2020). PERAN ORANG TUA DALAM MENDAMPINGI ANAK DI RUMAH SELAMA PANDEMI COVID-19. JCE (Journal of Childhood Education), 4(2), 71-81. https://doi.org/10.30736/jce.v4i2.256

Lestariningrum, A. (2014). PENGARUH PENGGUNAAN MEDIA VCD TERHADAP NILAI-NILAI
AGAMA DAN MORAL ANAK. Jurnal Pendidikan Usia Dini, 8(2), 195-206.

Mashar, R. (2011). Emosi Anak Usia Dini dan Strategi Pengembanganya. Prenada Media.

Mintorogo, J. M., Adib, A., \& Suhartono, A. W. (2014). PERANCANGAN MEDIA INTERAKTIF PENGENALAN ALPHABET BERBASIS ALAT PERMAINAN EDUKATIF UNTUK ANAK USIA 2-4 TAHUN. Jurnal DKV Adiwarna, I(4), 13.

Mubarakah, W. W., \& Munastiwi, E. (2020). Pelaksanaan Program Tahfidzul Qur'an Berbasis Online Masa Pandemi Covid-19. TADRIS: Jurnal Pendidikan Islam, 15(2), 184-194. https://doi.org/10.19105/tjpi.v15i2.3 725

Munastiwi, E. (2020). Colorful Online Learning Problem of Early Childhood Education During the Covid-19 Pandemic. Al-Ta Lim Journal, 27(3), 227-235. https://doi.org/10.15548/jt.v27i3.663

Mutiah, D. (2015). Psikologi Bermain Anak Usia Dini. Kencana.

Nurdin, N., \& Anhusadar, L. (2020). Efektivitas Pembelajaran Online Pendidik PAUD di Tengah Pandemi Covid 19. Jurnal Obsesi: Jurnal Pendidikan Anak Usia Dini, 5(1), 686-697-697.

https://doi.org/10.31004/obsesi.v5i1. 699

Nurwita, S. (2020). MENINGKATKAN PERKEMBANGAN SENI ANAK MENGGUNAKAN MEDIA SMART HAFIZ DI PAUD AIZA KABUPATEN KEPAHIANG. Early Childhood Research and Practice, 1(01), 34-37. https://doi.org/10.33258/ecrp.v1i01.1 070

Pramana, C. (2020). Pembelajaran Pendidikan Anak Usia Dini (PAUD) Dimasa Pandemi Covid-19. Indonesian Journal of Early Childhood: Jurnal Dunia Anak Usia Dini, 2(2), 115-123. https://doi.org/10.35473/ijec.v2i2.55 7 
Salamah, S., Idawati, I., \& Sugandi, B. (2020). Moral value of smart hafiz toys for children worship series with the title "don"t lie." PROCEEDING UMSURABAYA, O(0), Article 0. http://103.114.35.30/index.php/Pro/a rticle/view/5967

Saputra, N. E., \& Ekawati, Y. N. (2018). Praktikalitas Buku Saku Digital (digital book pocket) APE Tradisonal. PROSIDING SEMINAR NASIONAL PSIKOLOGI UNISSULA, $\quad O(0), \quad$ Article 0. http://lppmunissula.com/jurnal.unissula.ac.id/in dex.php/psnpu/article/view/3793

Sartika, \& Munastiwi, E. (2019). Peran Guru Dalam Mengembangkan Kreativitas Anak Usia Dini Di TK Islam Terpadu Salsabila Al-Muthi' in Yogyakarta. Golden Age: Jurnal Ilmiah Tumbuh Kembang Anak Usia Dini, 4(2), 35-50.

Suryana, D. (2016). Pendidikan Anak Usia Dini: $\quad$ Stimulasi \& Aspek Perkembangan Anak. Prenada Media.

Susanto, A. (2011). Perkembangan Anak Usia Dini: Pengantar dalam berbagai aspeknya. Kencana.

Widayati, J. R., Safrina, R., \& Supriyati, Y. (2021). Analisis Pengembangan Literasi Sains Anak Usia Dini melalui Alat Permainan Edukatif. Jurnal Obsesi: Jurnal Pendidikan Anak Usia Dini. https://www.obsesi.or.id/index.php/o bsesi/article/view/692

Wulandari, H., \& Purwanta, E. (2020). Pencapaian Perkembangan Anak Usia Dini di Taman Kanak-kanak selama Pembelajaran Daring di Masa Pandemi Covid-19. Jurnal Obsesi : Jurnal Pendidikan Anak Usia Dini, 5(1), 452-462-462. https://doi.org/10.31004/obsesi.v5i1. 626

Yus, A. (2011). Model Pendidikan Anak Usia Dini. Kencana.

Zaini, H., \& Dewi, K. (2017). PENTINGNYA MEDIA PEMBELAJARAN UNTUK ANAK USIA DINI. Raudhatul Athfal: Jurnal Pendidikan Islam Anak Usia
Dini,

l(1),

81-96.

https://doi.org/10.19109/ra.v1i1.1489 